\title{
Reminiscences of Ervin G Erdös
}

\author{
Rajko lgić1,2,3
}

\section{ABSTRACT}

This article includes personal reminiscence of the great scientist Ervin G Erdös (1922-2019). Dr Erdös was born in Budapest, where he studied medicine. He finished his medical school in Munich, and obtained MD degree in 1952. There he joined, as a postdoctoral fellow, Professor Eugen Werle who had earlier discovered kallikrein, an enzyme that liberates kinins from kininogen. Dr Erdös continued his work on peptides and peptidases at the universities of Pittsburgh, Oklahoma City, Dallas and Chicago. In his eighties, he retired from the University of Illinois, Chicago. His numerous contributions to science belong to three important areas: 1) enzymes that generate, inactivate, or modulate the activity of kinins and other biologically active peptides, 2) angiotensin-converting enzyme and 3) kinin receptors. These discoveries contributed to our understanding of several bioactive peptide systems. Dr Erdös also found important interactions of the renin-angiotensin and kallikrein-kinin systems.

Key words: renin; ACE, angiotensin; kallikrein; kinin; peptides.
(1) Department of Anaesthesiology and Pain Management, John Stroger Hospital of Cook County, Chicago, Illinois 60612, USA.

(2) Faculty of Medicine, University of Banja Luka, 78000 Banja Luka, the Republic of Srpska, Bosnia and Herzegovina.

(3) Medical Centre Sombor, 25000 Sombor, Serbia

Correspondence:

RAJKO IGIĆ

E: r.igic@excite.com

\section{ARTICLE INFO}

Received; 2 December 2019 Revision received: 8 December 2019 Accepted: 11 December 2019

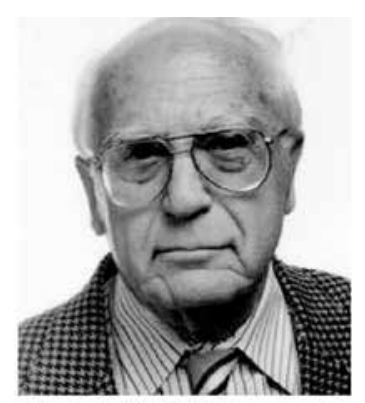

Ervin G Erdös (1922-2019)
ERVIN G ERDÖS was born in Budapest, in 1922, where he finished Realgymnasium, which is analogous to high school, just at the beginning of World War II. However, since he was Jewish, he could not enter the university. He spent several years working as a steelworker, and later at forced manual labor. Finally, he and his father were deported together to the Sachsenhausen concentration camp in Berlin. ${ }^{1}$ At the end of war, he successfully escaped and made his way home. After the war, Ervin entered the medical school in Budapest, but the regime banned him from finishing his final year because he was marked as a dissident. Then he luckily smuggled across the minefields and armed patrols between Hungary and Austria and came to Munich. It took him only one year to learn German and take the final examinations to get his MD degree from the University of Munich in 1950. In 1952 he joined the laboratory of Eugen Werle as a postdoctoral fellow in the Department of surgery where kallikrein, an enzyme that releases kinins from kininogens, was earlier discovered. Research on kinins in $\mathrm{Mu}-$ nich inspired his permanent interest in peptides and peptidases (Figure 1).
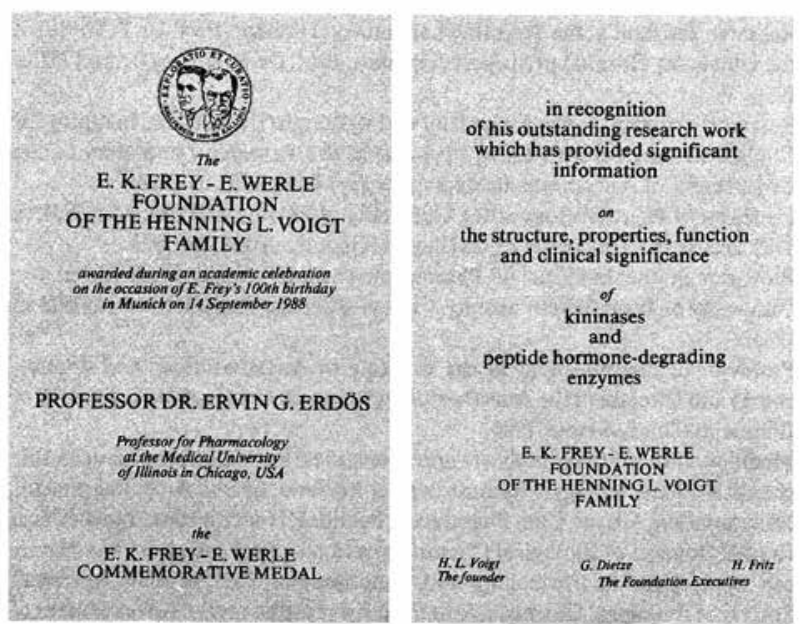

Figure 1: E K Frey - E Werle Commemorative Medal awarded on 14 September 1988 to Professor Ervin G Erdös for his scientific contribution in the research of peptides.

Soon, Dr Erdös emigrated to the USA, where he worked in Pittsburgh, Oklahoma City, Dallas, and Chicago. He retired in his eighties from the University of Illinois at Chicago. 


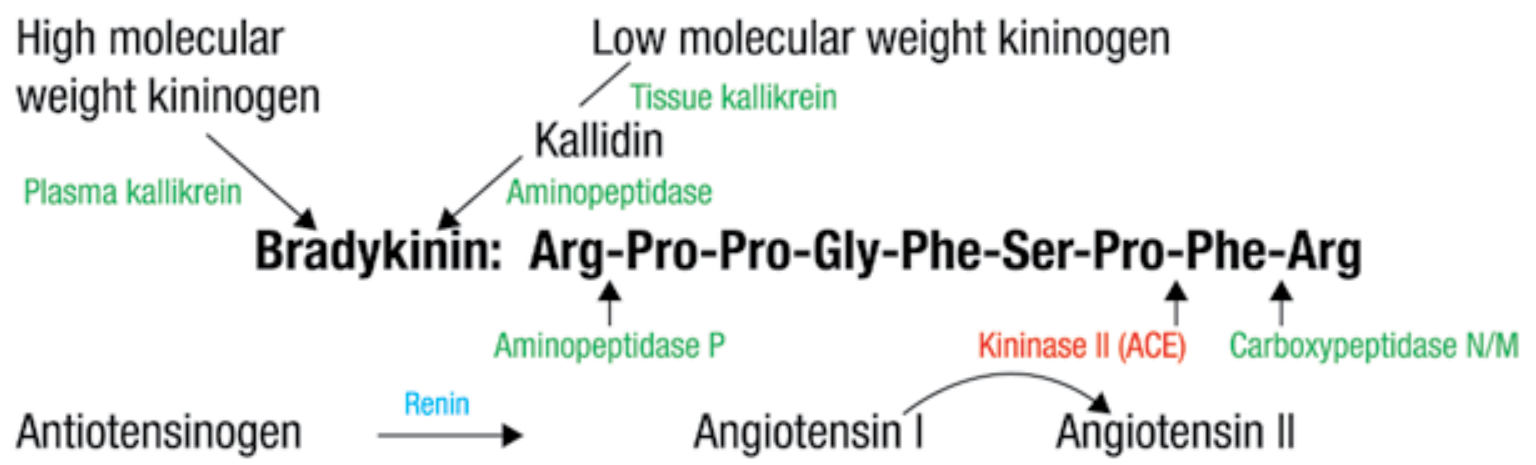

Figure 2: Peptides and peptidases of the kallikrein-kinin system (KKS) and a portion of the renin-angiotensin system.

The enzymes in the KKS are shown in green, while renin is shown in blue; angiotensin -converting enzyme (ACE), which acts in both systems, is shown in red. Credit Journal of Biological Chemistry. ${ }^{5}$

I first met Dr Ervin G Erdös in 1969 at the Fourth International Congress of Pharmacology in Basel, Switzerland while I was working at the experiments for my $\mathrm{PhD}$ dissertation. During the dinner that night organized for all participants, I was sitting next to a distinguished gentleman with dark-rimmed glasses. When I introduced myself, he presented his name: "Ervin Erdös from Oklahoma City". We enjoyed an extended conversation that night, and also during a day off for all participants, when we spent together an enjoyable visit to Lake Lucerne that ended with his invitation to me to come to the USA to work with him. In January of the following year I defended my thesis at the University of Sarajevo. I then went to the USA as an exchange scientist for one year to work on the metabolism of vasoactive peptides in Dr Erdös' laboratory.

Dr Erdös discovered aminopeptidase, an enzyme that removes the N-terminal Lys of kallidin to form bradykinin, while a different aminopeptidase (aminopeptidase P) and carboxypeptidase (kininase I) deactivate bradykinin by removing the N-terminal $\operatorname{Arg}^{1}$ or the C-terminal Arg ${ }^{9}$, respectively. He also discovered another enzyme in blood and tissues that removes the C-terminal $\mathrm{Phe}^{8}$-Arg ${ }^{9}$ dipeptide; he named this enzyme kininase II. Later on, he and his co-workers showed that kininase II was identical to angiotensin I-converting enzyme (ACE). ${ }^{2,3}$ This discovery connected the kallikrein-kinin system (KKS) with the renin-angiotensin system (RAS; Figure 2). Dr Erdös also discovered prolylcarboxypeptidase, a peptidase that deactivates angiotensin II and other peptides. His numerous contributions to science for more than half of the century span three important areas: 1) enzymes that generate, inactivate, or modulate the activity of kinins and other biologically active peptides, 2) ACE, and 3) kinin receptors. These discoveries contributed to our understanding of several bioactive peptide systems. Dr Erdös also found important interactions of the RAS and KKS. He and his colleagues presented evidence that $\mathrm{ACE}$ and the bradykinin B2 receptor physically interact with the cell membrane, and that an ACE inhibitor induces a conformational change that activates the signalling pathway. The ACE inhibitors also bind directly to the $\mathrm{B} 1$ kinin receptor to upregulate $\mathrm{B} 1$ receptors in the cardiovascular system that are usually expressed in inflammation, injury, or presence of cytokines. ${ }^{4}$

Among his other studies, while in Oklahoma City as a member of the Medical Faculty, Dr Erdös studied the mechanisms of septic and haemorrhagic shock. When the first ACE inhibitor from snake venom (SQ2081, called teprotide) became available, he used it to establish that the endotoxin-induced compensatory rise of blood pressure in shocked dogs was due to the activation of the RAS. It is well known that endotoxin initially causes a sharp drop in the mean systemic arterial pressure, but soon after this decrease, the pressure temporarily rises. Dr Erdös showed that the pressure rise resulted from the release of angiotensin II by ACE.

While Dr Erdös was working at the University of Oklahoma, Dr Edward Frohlich told him that he had difficulties with the cannulation of pulmonary blood vessels for studies of pulmonary circulation in rats. Dr Erdös humorously told him: "I have a man who can cannulate a mosquito." So, Dr Frohlich's technician anaesthetised a rat and invited Ervin and me to come. With the audience of three men, I then successfully cannulated the 
pulmonary vessels. This made everyone happy, especially me. Dr Frohlich's technician learned how to do it at the same time; I was glad that my reputation did not suffer, and Dr Erdös was perhaps the happiest of all, because his claim of "mosquito cannulation" became more than simply boasting.

When Dr Erdös moved his laboratory from Oklahoma City to Dallas, Texas, I spent my three vacations, about two months each time, working with him. His laboratory was much better equipped than ours in Sarajevo and Tuzla, so I could continue some work that I began in Sarajevo, namely my studies of the ACE in the retina. ${ }^{6,7}$ In the following years many other researchers become interested in ocular ACE; in fact, in 2016 more than 180 publications were retrieved on this subject. $^{8}$ Van Haeringen stated in the British Journal of Ophthalmology: ${ }^{9}$ "Ophthalmic literature concerning the RAS started in 1977 with a study by Igić and co-workers on the detection of ACE activity in homogenates of the retina." Thanks to Dr Erdös, I was able to discover the presence of this enzyme and other peptidases in the eye, both in animal and human tissues. ${ }^{10}$ I was not the only one he helped though. Dr Erdös also helped more than a dozen other young researchers from various countries, including USA, Japan, China, France, Serbia, and Germany. Their names are listed as co-authors on his many published papers.

In addition to the basic scientific research, Dr Erdös made substantial improvements in the methodology required for his studies. One is related to the recording method, the kymograph. This instrument was initially invented by a German physiologist, Carl Ludwig, in the 1840s. In many physiological and pharmacological laboratories around the world, a kymograph was an essential instrument. I also used one in experiments for my $\mathrm{PhD}$ thesis to record muscle contractions. ${ }^{11,12}$ One piece of thread was attached to a strip of smooth muscle in a tissue bath, and the other was connected by the thread to a lever, which scratches the smoked paper on a slowly rotating drum when the muscle contracts. After each experiment, the record was preserved by fixing the paper with shellac.

To avoid this laborious procedure and the potential loss of data caused by accidental touch by a researcher's hand or elbow, Dr Erdös and two engineers at the Mellon Institute found a replacement. It consisted of a sensitive balance, one arm was connected by a thread to the isolated muscle tissue in the bath and the other to a transformer, while the sensitivity of the device was controlled with a demodulator box. Muscle contractions were then registered on a recorder in ink. To publish this technical innovation, Dr Erdös submitted the manuscript to one of the best journals in pharmacology. However, the editor rejected it because one referee stated that there is absolutely no need for such an instrument. ${ }^{1}$ A few months later, in 1962, the paper was published in the Journal of Applied Physiology and it was cited in several textbooks.

When I worked with the isolated muscle tissue preparations in Dr Erdös' laboratory in Oklahoma City, I used this original equipment instead of a kymograph, taking advantage of this innovation. After several years, miniaturised electronic transducers for registration of isotonic and isometric contractions became commercially available, and they are still used today in many laboratories.

During his early studies on peptides and peptidases in 1962, Dr Erdös found that bioactive peptides produced by the RAS could never be useful medication, because they were so rapidly inactivated by enzymes; yet the agents that block their effects or inhibit their enzymatic degradation or production could alter their role in certain medical conditions. ${ }^{13,14}$ This concept led to the development of the clinically useful ACE inhibitors.

In "A short history of my life and work entwined" written on 145 pages, ${ }^{1}$ Dr Erdös describes his school years in Budapest, saying that he was "a remarkably average, uninterested, and generally bored student." For eight years in his middleand high-school he and his close friend George Weber (who became a Distinguished Professor at the University of Indiana) were preoccupied with playing ball and girl-gazing. Dr Erdös continued, "Had a vote been taken in that school, George and I would certainly have tied for the most unlikely students to become members of the Hungarian National Academy of Science." Indeed, that happened to both of them much later. Today's educators who pressure students to have perfect marks in order to be accepted at the university, might consider that creativity does not depend on grades alone. 


\section{Epilogue}

On Tuesday, November 12th, Dr Erdös called me. We talked for about ten minutes. He invited me for a visit and at the very end, added: "Rajko, despite my bad condition, on some days, I feel quite well, and I would like to go with you out to a café." I knew that his health was not good enough for that, so I decided to visit him instead. I would make him some Turkish coffee, just like we often did when he visited my lab in Sarajevo as a Fulbright Fellow-Visiting Professor. When I went to visit him that Thursday, I brought with me finely ground coffee, a džezva (vessel for extracting the coffee) and small porcelain cups - all the stuff needed to prepare the Turkish coffee.

I waited for Ervin to join me in the salon and reminisced about our long relationship. I could see into his study from where I sat. The things on his desk were unchanged from the times he spent working there. In fact, I had worked with him in that room on a long manuscript that I had written for the Journal of Biological Chemistry. ${ }^{5}$ Together the salon and study in Dr Erdös' apartment were like a beautiful art gallery with many fine paintings on the walls and large windows open to a magnificent view of Lake Michigan. The lake is about a quarter of a mile away, but on this sunny day, it shone like another piece of the fine art that he cherished.

While I waited for about 10 minutes, many thoughts arose in my mind. When I left my apartment in Tuzla due to the war in Bosnia, I lost all my possessions, including paintings by various important artists. I lost these and other important things, but I saved my life. Now my dear friend and colleague would also lose these valuable art works that he has been collecting for many years and he would also lose his life. The difference between my situation in Tuzla and his in Chicago is that in the former the deep sadness comes a long time later, while in the latter it comes beforehand. In Ervin's case the loss would not be a loss of material possessions, but the loss of relationships with family, friends, and the many colleagues he helped during his long scientific career.

My thoughts were interrupted when Ervin appeared in his wheelchair. He was delighted in showing me of his art collection, including Hungarian-made vases and paintings from around the world. He talked slowly, and sometimes could not finish his thought, but when he showed me a painting by an artist from Sombor, he remarked that it was a pity that Yugoslavia, a beautiful country, had disintegrated into pieces. I prepared the Turkish coffee, and together with Ervin's wife, Sara, we had a long, friendly conversation around the kitchen table. Ervin asked about my wife and sons and said he would like to see my recently published book on geriatrics that I had brought to show him. The book is printed in Serbian, but it had many words in Latin and English and several illustrations. Ervin examined the book for about twenty minutes, only occasionally asking me the meaning of some words.

The next day Ervin went to the hospital for a scheduled appointment, but unfortunately, he did not return home. His condition suddenly worsened, and he died two days later, on Sunday, 17 November 2019. He was 97 years old.

\section{ACKNOWLEDGEMENTS}

None.

\section{CONFLICT OF INTEREST}

None.

\section{REFERENCES}

1. Erdös EG. Peptides and the enzymes that release or inactivate them: A short history of my life and work entwined. In: Semenza G, and Turner A J, eds. Selected topics in the history of biochemistry: personal recollections VIII. Comprehensive Biochemistry. Vol. 43. New York: Elsevier B.V.; 2004. p. 279-354.

2. Yang HYT, Erdös EG, Levin Y. A dipeptidyl carboxypeptidase that converts angiotensin I and inactivates bradykinin. Biochim Biophys Acta 1970;214:374-6.

3. Igić R, Sorrells K, Nakajima T, Erdös EG. Identity of kininase II with an angiotensin I converting enzyme. In: Back N, Sicuteri F, eds. Vasopeptides. Plenum Press, New York; 1972. p. 149-153.

4. Erdös EG, Deddish PA, Marcic BM. Potentiation of bradykinin actions by ACE inhibitors. Trends Endocrinol Metab 1999;10:223-9.

5. Igić R. An exploration of bioactive peptides: my collaboration with Ervin G. Erdös. J Biol Chem 2018;293:7907-15.

6. Igić R, Robinson CJG, Erdös EG. Angiotensin I converting enzyme activity in the choroid plexus and in the retinal. In: Buckley JP, Ferrario CM, eds. Central actions of angiotensin and related hormones. New York: Pergamon Press; 1977. p. 23-27.

7. Igić R, Kojović V. Angiotensin I converting enzyme (ki- 
ninase II) in ocular tissues. Exp Eye Res 1980;30:299303.

8. Choudhary R, Singh M, Kapoor MS, Singh A, Bodakhe $\mathrm{SH}$. Therapeutic targets of renin-angiotensin system in ocular disorders. J Curr Ophthalmol 2016;29,7e16. http://dx.doi.org/10.1016/j.joco.2016.09.009.

9. Van Haeringen NJ. The renin-angiotensin system in the human eye. Br J Ophthalmol 1996;80:99-100.

10. Igić R. Four decades of ocular renin-angiotensin and kallikrein-kinin systems (1977-2017). Exp Eye Research 2018;166:74-83.

11. Igic R. Effect of oxotremorine on the acetylcholine content of whole brain and various brain regions in the pigeon. Br J Pharmacol 1971;42:303-4.
12. Igić R, Stern P. The effect of oxotremorine on the "free" and "bound" brain acetylcholine concentrations and motor activity in beri-beri pigeons. Can J Physiol Pharmacol 1971;49:985-7.

13. Erdös EG. Hypotensive peptides: bradykinin, kallidin, and eledoisin. In: Garattini S, Shore PA, eds. Advances in Pharmacology. Vol. 4. New York: Academic Press; 1966.

14. Erdös EG, ed. Bradykinin, kallidin, and kallikrein. In: Handbook of Experimental Pharmacology. Vol. 25. Heidelberg: Springer-Verlag; 1970. 